\title{
Food, malls and the politics of consumption: South Africa's new middle class
}

\author{
Sophie Chevalier ${ }^{\mathrm{ab}}$ \\ ${ }^{a}$ Associate Professor, Department of Sociology and Anthropology, University of Franche-Comté, \\ Researcher at the Institut Interdisciplinaire d'Anthropologie du Contemporain (LAU)/EHESS-Paris, \\ 30 Rue Mégevand, 25000 Besançon, France. \\ ${ }^{\mathrm{b}}$ Research Associate, Department of Anthropology, University of Pretoria, South Africa.
}

Consumption has become a central focus in South African politics, one that hinges especially on evaluation of the behaviour of the new Black middle class. Based on an ongoing ethnographic study of Durban, mainly among the lower middle or 'professional' class across a range of racial categories, the article addresses three aspects of this question: food provisioning and consumption across and within the various communities; interaction in shared social spaces that were previous segregated, especially shopping malls; and moral discourses in the media concerning this new class. The so-called 'Black diamonds' are a South African urban type of the sort labelled by Benjamin as a phantasmagoria. South Africans are willing to experiment beyond the boundaries of their native communities and there is an emergent national middle class culture, but there are marked regional differences and nothing yet that would amount to 'creolisation'.

Keywords: Black Diamond; Consumption; cooking; Durban; food provisioning and consumption.

\section{Introduction}

Since 2008 I have carried out intermittent ethnographic research in eThekwini/Durban (hereafter Durban) on the new middle class - across a range of racial categories; and for the last three years one major focus has been on food provisioning and consumption. I am interested, as most South Africans are, in the relationship between race and class, and the possible emergence of a non-racial middle-class. The growth of a new middle class of consumers has been and still is taken as a measure of success in transforming the country's society and politics. If a middle class is not made by how it spends money (consumption), but by its sources of income and property, consumption has certainly been used to define individual members of such a class. 
When I started out, I decided to focus my attention on the two features commonly taken in public discussions as signs of the emergence of a new non-racial middle class: access to consumption patterns previously reserved for Whites; and residential mobility, that is, households that left the townships for the formerly white suburbs. Much of my subsequent research has been concerned with social interaction in shared public spaces that were segregated under apartheid: residential areas and car transport, use of the sea front (beach and promenade) and shopping malls by all classes and communities as free spaces (e.g. Chevalier 2012). In the process I extended my initial focus to include all racial communities. This article first looks at consumer behaviour, approached more narrowly through the study of food provisioning; second I address the role of shopping malls in developing new patterns of consumption and social interaction; finally I take up public discourse about the new middle class, as represented by discussion of the socalled Black Diamonds. For South Africa, I argue, this is a new 'urban type' in Benjamin's (2006) sense of a phantasmagoria.

My general hypothesis is that the new multi-racial middle class recreates the South African nation through their consumption, while at the same time making new links to world society. A vast new arena of consumer choice, which was the preserve of Whites not long ago, has been opened up to Blacks - albeit often on credit. This offers the latter an opportunity to participate in national "prosperity", while their fascination with international brands reflects a similar desire to participate in global consumption. My work also aims to add a neglected regional dimension to marketing and media discussions of race and class. Marketing specialists treat South Africa as a single entity stratified before by race and now by social class. Durban offers an interesting commentary on these generalisations because of its specific social history, combining the former British colony of Natal, a strong Indian presence (it is the largest Indian city outside India) and the home of the Zulus, South Africa's largest ethnic group.

My research has been based in part on visiting individual shops and malls, on interviews with shopkeepers and with families at home, mostly women from all communities ${ }^{1}$.

1 Until now I myself have interviewed, members of some forty households once or more times. Half of them were Black, the others Indians, White and Coloured (two were multiracial 
Fieldwork was carried out in 2011 (six weeks), 2013 (four weeks) and 2014 (six months). I contacted my middle class informants through personal networks based on neighborhood, schools and workplaces. I met some of these women several times; and I exchange a number of items with them when I am in Durban -- recipes, tips about cookery books, shops addresses and foodstuffs. I begin here by summarising my interviews with women on shopping, food consumption and cooking. I have also consulted numerous media sources that offer advice to consumers, such as TV programmes, cookery books and women's magazines (two of which, Bona and Your Family, I am studying intensively).

\section{Food consumption}

Studying food consumption is for me part of a long-term research project, which includes urban food supply chains - markets, supermarkets, etc. - and is comparative in scope (see Chevalier, on France and Britain, 1997 and 2007; Chevalier and Escusa on South Africa, 2011). Looking at food allows us to integrate a wide range of questions because, although we need to eat to live, eating is also a principal vehicle for sharing social life and for expressing a range of lifestyles. Moreover, food is a deep symbol of inherited identities. Every group has its 'soul food' and the taste for this changes more slowly than our willingness to experiment with fast foods imported from around the globe. Without doubt, the residents of cities like Durban today have a vastly expanded repertoire of foodstuffs at their disposal. Yet this development, far from leading to a homogenisation of food regimes, has allowed people everywhere to push out the boundaries of their culinary experience, while still defining their own authenticity in quite narrow ways. People go out to buy food, both raw and cooked, they consume it at home or in cafes and restaurants, with family and friends. By focusing on this movement of people as consumers, linked to what they eat, where and how, we may be able to reveal complex patterns of interaction across public and private spheres, as well as old and new forms of social, ethnic and religious identity. Clearly, food is "good to

couples). With few exceptions, they had children; and a third of these households included extended kin. They were all between 30 and 50 years old ; but they distinguished themselves as generations by whether they came to maturity before or after the early 1990s. 
think with" when we contemplate the transformations now taking place in South Africa. ${ }^{2}$ Also middle class consumption, especially for the lower middle-class that I have focused on, can be precarious, even fragile; and nothing illustrates this more vividly than fluctuations in food-buying habits.

\subsection{A tight food budget}

My material shows that everyone took great care when budgeting for food and often observed strict limits on this item of expenditure. In my interviews, I noticed a strong concern to keep food expenses to a budget, even if household income had increased substantially over the years. ${ }^{3}$ Food generally accounts for a smaller proportion of middle-class budgets than transport, for example; but its cost may be varied more flexibly. Some of the less well-off members of my sample complained about the rise of food prices over the last few years, claiming that food is their main expense, absorbing up to $40 \%$ of their income in some cases. Regardless of its budget share, most people I interviewed were keenly aware of food prices and could calculate their family's food costs - "I spend on average R3500-4000 per month for the whole family" (Lameez, Indian, married, two children, housewife, in her mid-thirties). South African women's magazines read by my informants have large sections offering advice to households, especially on food - not only how to cook, but also how to spend your money wisely on food. You, for example, receives praise for its cooking section, where the price of a meal is itemised or a weekly food budget is suggested. The monthly magazines, Bona and Your family, have a middle-class readership, the first mostly Black women and the second women of several races; sometimes, they too provide budgets for meals and receipes.

\footnotetext{
${ }^{2}$ There is a huge literature on food and cooking. I will mention here only the sources I used directly in analysing the results presented.

${ }^{3}$ No-one takes out a loan to finance food purchases or at least will confess to have done so. This contrasts with an article published in the Mail\&Guardian: "South African consumers borrowing for basic needs", Mail\&Guardian, October 24th, 2012. http://mg.co.za/author/penwell-dlamini
} 
Everyone takes advantage of the cost reductions made possible by large-scale marketing outlets, relying on end-of-month 'specials', bulk-buying and comparing prices. They go for wholesalers like Makro or 'hampers' in Fruit\&Veg and buy in bulk at the end of the month, creating a noticeable "month end payday buying frenzy" in the shopping centres. Usually the people I met buy some food for the whole month - basics such as maize meal, oil, onions, rice and some meat - the week-end after they receive their salaries (around the 25 or 27th); while small purchases of bread or milk are made daily or weekly. They are ready to drive far for a good bargain after careful and frequent screening of the 'specials' in mailboxes and newspapers (sometimes distributed to the kids at school). "I check out all the promotional literature by the supermarkets to identify specials; I plan my purchases accordingly and then I stock up on them!" (Bronwyn: Coloured, married, one child, in her early thirties). She has a system of envelopes with money linked to specific goods, what Zelizer (1997) calls "earmarking"; for Bronwyn money is not just an abstraction. A few months after this interview, she and her husband bought a small house in Berea and she left her job as a clerk at a police station to take care of their little daughter full-time. Some of the women participate in stokvels or more specifically in saving clubs which aim to buy groceries in bulk at the end of the year, in order to be able to prepare for Christmas celebrations without too much strain. These societies give an empowering feeling of being in control of your expenditure, while generating solidarity between women who share the plight of having to buy food for their families on a tight budget (Counihan 1998).

Meat receives special treatment. This accords with what anthropologists know about human relations with animals and not least with their death. Meat is particularly celebrated in South Africa, especially by the Whites when grilled on a barbecue. Most meat is bought in a butcher's shop, often in bulk like a half lamb at Bluff Meat, for example. Many Black consumers do not hesitate to return to their former townships at weekend to buy meat or to cross the city for the sake of a special shop. The same is true of my informants in France who choose carefully where they buy meat. My informants argue that each community has its preferred meat and cooking style and they sometimes reproduce stereotypes, claiming that Blacks like to eat cow tripe with dumplings cooked in various ways; the Whites go for chicken à la king or pork roast and sausages; chicken and lamb curry are the Indians' favourite. But when faced with the rising cost of food, many of them were inclined to cut back on buying meat. 
Despite being a port and seaside resort, Durban has very few fish-shops, since its consumption has always been quite low. This paradox is related to the food traditions of the different local groups: Indians, Whites and Coloureds traditionally consumed more fish than the Zulu majority. Fish and seafood are as a result mostly imported from Mozambique, often sold frozen and quite expensively. Even so, probably as part of a movement towards healthy eating, everyone now says that they eat or would like to eat fish. But most of my informants claimed to know little about how to cook it and preferred to eat fish in restaurants or as a takeaway. Ocean Basket is a favourite among all groups, where the family can eat fish and shrimp after shopping in a mall.

Young couples usually go shopping with their partner, but Maureen (Black, divorced, late forties and with five people to feed) goes with her older daughter; other women with their sister or mother. Often also people shop for other members of their family who are not living with them, especially parents who still live in the townships or elsewhere. These monthly food shopping expeditions often end up with a lunch in one of the numerous fast food chains or restaurants, which are located in shopping centres or malls, as a pay-off for undergoing the duty of shopping. Nevertheless, Durban people don't go out very often to restaurants, either because it's expensive or because they prefer to stay home at night, possibly for security reasons. One restaurateur told me that no more than 40,000 out of Durban's 3 million inhabitants ever go out to eat in the evening, to what he called a 'proper restaurant' -- with a chef and not part of a chain. They are more likely to go out for lunch because they can take the children.

\subsection{Take away and eating out: pushing the boundaries?}

If meat is each community's 'soul food', the women I interviewed described the same range of meals as their favourites for home cooking: macaroni cheese, roast chicken, 'lamb pie', lasagne and 'cottage pie'. Black women add 'pap \& meat' to this list. Apart from the recent rise of Italian food, a lot of these recipes share a British colonial heritage (Leong-Salobir 2011). Bronwyn, who claims to be coloured, says that as a result of being "in between" she has mastered all the community specialities from putu pap with meat and chakalaka to Indian curry. 
Although most South African women's magazines address a specific community readership, their cooking recipes are remarkably similar, varying mainly in the cost of recipes aimed at readers of different class, despite the fact that, in other respects (fashion, advice columns, etc.) their orientation is directed to one group only. Except on one element, the fat used in recipes: cooking recipes in African women's magazines never specify butter, always margarine. French historians like Braudel (1961) and Febvre (1961) have noted the distinctive use of fats there, historically and geographically; and Mauss (1926) has a general discussion about the use of butter (fresh and rancid) in the Mediterranean area. There are in fact two Frances: one, using butter in the North, the other olive oil in the South! Are there two South Africas?

My informants are also open to trying new kinds of food, making experiments, taking advantage of industrial food options and chain restaurants (including take away). But at the same time they stick quite closely to the food habits of their own communities; and some people are quite suspicious of what they consider to be 'European' or 'Western' food, such as pizza and sushi. Nevertheless, cooking styles are diffused by restaurants, above all as take-away dishes which people are very keen to try. At lunch time, queues line up in front of take- away stands which often sell the same dishes: chicken or mutton curry, grilled chicken, macaroni bolognaise, rice with minced meat, sausages and sometimes fish and chips. Once a week at least, the people I met and sometimes observed ate take away as a family meal on Friday or Saturday evening, bought at Wimpy, Steers or KFC or at local Indian or Italian take away restaurants: "We would go to KFC because my wife is paid on Friday" (Thutukani: Black, married, early thirties) or "I go to a mall where there are different take away restaurants, to buy different food, a pizza for my husband and son, a curry for me... " (Heidi, White, married to an Indian, three children, mid-forties). Few people go to a 'proper' restaurant as a couple or with a group of friends; sometimes they take the opportunity of offers; thus some Durban restaurants offer half price for women only. People also often discover restaurants through corporate events. Another way to eat out and to try new recipes is through church and community meals, very often based on a 'bring and share' principle.

The range of choice in South Africa, including Durban, is wide, extending to international chains like $K F C$, which is very popular, and Wimpy, national chains like Steers (founded by a Greek South African and now everywhere) or Nando's (a chicken 
peri-peri specialist founded by Mozambicans and common in Britain and Asia); or again there are many local restaurants, mainly Indian, Italian and Portuguese. This range allows South Africans to taste 'globalized' food like hamburgers or chicken and chips (KFC, Wimpy and Steers), but also more specific recipes, even if these are adapted to local palates: Indian-South African food, Italian-South African food, but also AfricanSouth African (Nando's with Mozambican recipes) or a combination of all these influences (Moyo).

In Durban, we should add curry which is thought to be emblematic of the Indian community, even if I was told by some Indian women that they had to learn how to cook it from their in- laws, since cooking in their family consisted mostly of British stews. Curry is nevertheless becoming a regional dish for Kwazulu-Natal because of the large number of takeaway restaurants that provide it. In fact, ready-made curry sauces available at the supermarkets are a great success with non-Indian customers who never learned how to mix the spices. Now, thanks to the sachets available, women like Jube and Mpumie (Black, sisters, both divorced, one with two children, both in their late thirties) can now prepare their weekly curry. In this way one community's speciality has become a staple of South African cuisine for all the middle classes in Durban.

This Durban lower middle-class is pushing out some of the boundaries of food preparation and consumption beyond their former silos. This process is made easier because, at this level of South African society, cooking is not configured by a strong contrast between high and low cuisine (Goody 1982). I would hazard the generalization that, in South Africa, there is no cooking style that is reserved to one class or community, but not the others. It just is not the case that only members of a particular cultural tradition (or professionals, usually men) know how to cook its food. I return to the question of South African national cuisine in my conclusions.

\section{Shopping malls as shared social spaces}

Food is bought mostly in supermarkets, which are usually located in shopping centres or malls. During the late apartheid era, access to mass consumption in the form of shopping malls was largely restricted to Whites. These malls - along with the development of tourism - represented one of the few investment channels open to 
White capital within the country, given the restrictions on its export imposed by the boycott. Since the ANC came to power, shopping malls have sprung up everywhere, reaching the whole population. Indeed President Zuma has been quoted as holding a vision of economic democracy that would grant every village its own shopping mall! There does not seem to be much public discussion in South Africa about how malls erode the base for local shops. At the same time, the government has made a big effort to improve service provision in the townships themselves. In collaboration with the private sector, they have launched shopping malls of a standard and scale equivalent to those built in the most affluent countries. In the Durban area, the relatively modest Umlazi Mega City comes to mind or the more ambitious Bridge City Shopping Centre in KwaMashu. In Chatsworth, an Indian township, the introduction of a new shopping mall provoked a raging controversy over ethnic ownership (Vahed and Desai, 2013). In any case, access to mass consumption, regardless of racial category, has become a central plank of economic and social policy in South Africa. And anthropologists, following Miller's example $(1998,2001)$, have shown that middle class people often judge the quality of life in their neighbourhoods by the shops. I remember Lindiwe, telling me: "It was wondeful when I first arrived here. Before it could take me 45 minutes to find a decent shop, but here they have everything! I never realised what an easy life the people here enjoy." (Black, married, three children, early forties). She moved with her family to New Germany from Umlazi township in 2003.

Malls, shopping centres and supermarkets, which are dominated by a few national chains, represent modern values, including hygienic standards. These mixed commercial spaces are leisure zones comparable in Durban to the seafront promenade. The great suburban malls there like Gateway and Pavillion are places for a family excursion at weekends, for stocking up on food before sharing a meal in a chain restaurant. The mall crowds are drawn from all South Africa's 'communities' (HoussayHolzschuch and Teppo 2009). But the clientele of Workshop, for example, in the city center near a transport hub for taxis, is overhelmingly Black and young, whereas the Musgrave centre (Durban's oldest, in a formerly White area) now attracts different groups at different times of the day or week: a White middle class crowd on working days, teenagers of all colours after school and more African and Indian families at the weekend. Durban city centre has its fair share of open markets and street stalls, often in 
areas associated historically with one community; but the people I interviewed went to these places only occasionally.

Middle-class consumption takes place in malls whose character is distinctively national and there is no question that being a citizen of the new South Africa means participating in the forms of sociality and anonymity afforded by shopping centres even more than actually buying stuff there. They are synonymous for many with modernity and abundance. In any case, these malls with their supermarkets frame middle-class consumption as national South African practice. A comparative perspective might allow us to see how participation in mass consumption by South Africans other than Whites, after a long period when the country was closed in on itself, may be a way of affirming ones political stance there, of declaring an attachment to the nation while at the same time making links with the rest of the world through buying international brands. In a study of Jewish immigration to New York from Eastern Europe at the beginning of the 20th century, Heinze (1999) showed how participation in the early stages of American mass consumption was one way that this community expressed its attachment to the new society. The abundance of commodities there was - and probably still is - a marker of North American identity. South Africa's malls, where many people go just to hang out without necessarily buying anything, show off an abundant world of consumption, within arm's reach.

If everyone likes the shopping facilities of malls, we may wonder if they can give people the social life they want or a sense of identity comparable to being located in a specific neighbourhood. Many of my Black and Indian informants go once a week to shop for specific items in their old neighbourhood. Bronwyn, who lives in formerly white Berea but was born in Wentworth, a Coloured neighbourhood, goes back there to shop for meat, to have her hair done and to go to church. The newspapers often stigmatise this kind of behaviour, describing a tension between middle class aspirations that they consider to be westernised and this attachment to ones "cultural roots" (Chevalier 2010; see also Chevalier 2007 for a French example). Simon Wood's documentary, Forerunners, shown at the Durban film festival in July 2011, addresses this question through stories taken from South Africa's emerging Black middle class. The director asks people in front of the camera to compare "the traditional views of 
their childhood with Westerm consumerism that rules their professional lives" (according to his introduction). Modernity is clearly represented as the world of the city and contemporary consumption. The film reveals in a nuanced way the explorations of four individuals. This kind of reflection on the meaning of tradition and modernity is important for South African research if we wish to place the phenomenon of the new middle class in a comparative perspective. The modern/traditional contrast, not least in this film, hinges always on an opposition between the city, the mall and upmarket consumption - a world associated with White colonialism - and a rural African world. Such a vision recapitulates the myth that South Africa's cities were invented exclusively by Whites, thereby implicitly endorsing a claim that behaviour in the country's new social spaces should conform to White standards (Ballard 2004).

This last example leads me again to ask how people define belonging to this lower middle class: some of my Black and Indian informants were adamant that it was the chance to have a house and food, then to have access to other goods and services, often shared with your family. Priya (Indian, married, late thirties, living with her divorced sister and her son) was very specific: "We are middle class because we are above the bread-line, we can afford food, a flat and two cars. Sometimes we can afford e bit more, a piece of cloth for me, a toy for my nephew who lives with us. But we can't afford to go to the restaurant everyday like the upper-classes. We can vary our diet but we need to budget at the same time, we can't buy everything we want". To be able to afford a little more that the basics makes the difference, just as to have some consumer purchasing power is associated with agency. But this feeling of upward social mobility is often linked to fear of losing it, which probably distinguishes this from other social classes. The people I interviewed still cling more to their community of origin for selfidentification than to any middle class identity, which is in any case fragile. They know that their power of consumption is indeed quite limited even if it is used to define them as a class.

My Black informants also often felt that they were novice consumers, because shopping and access to services more generally were so limited before. This situation recalls historical accounts of the birth of mass consumption in the United States and Europe in the late 19th and early 20th centuries, when the middle and working classes had to learn how to consume (Strasser et al. 1998; Zelizer 1997). This literature also emphasizes the 
role of advertising and brands in the formation of consumer behaviour. The people I interviewed, especially those over 40 , expressed an attachment to brands that had been around for a long time: because we have always seen them around us. Knowledge of these brands was a kind of shopping guide for many consumers. Global brands build links to the outside world. Also, the principal victims of segregation have little capital, savings or inheritance to draw on and must go into debt if they wish to consume on any scale (James 2012). As one of them told me, The apartheid system made sure that we knew little about money, since we were supposed not to have any! (Muntu, Black, widowed, late thirties, one child).

The point of comparing South Africa today with historical examples elsewhere is not to imply a unilinear process of modernisation, but to identify questions that might not otherwise be raised. Thus, who is teaching South Africans how to consume and through which media? When I analyse the cooking recipes and advice in women's magazines, I am struck by the sheer prominence there of big companies and retail chains.

\section{Consumer behaviour: a political question?}

South African marketing professionals have lately been looking for a device that would allow them to describe consumers without using the system of classification prevalent under apartheid. The idea of a Living Standards Measure (LSM) was perfect for this purpose since it allowed them to define social categories without mentioning a person's race (Burgess 2002). In consequence - which is just the first paradox of this conflicted practice - it has been widely adopted as a means of identifying the life-style of a social group whose only common characteristic is the colour of their skin. When it became impossible to abstract completely from race, which after all had been synonymous with class as a marker of individual identity for over a century, it was replaced by the term 'culture', conceived of as a mark of collective belonging. Also, the LSM makes no reference to locating consumers in space: interviews with professionals in charge of marketing automobiles, for example, revealed that this new middle class was taken to be nationally homogeneous and no interest was shown in any regional differences that might exist. The second paradox, however, is that the same marketing professionals invented another word for this class, the Black Diamonds, which reintroduced race by the back door and was then taken up avidly by the media. The first publication of the 
Unilever Institute to use this term was its 2007 Survey: On the Move. This study was based on interviews with 750 adults in South Africa's main cities drawn from categories 9 and 10 of the LSM (Krige 2011: 297f). And when it comes to projecting images of the new consumer classes, the media are much more influential than social scientists (Chevalier 2010). Indeed the latter often draw on labels created by professional specialists for their own analyses. No representation of this sort has been more debated in the South African media than the Black Diamonds. The term has also found its way into literature, for example as the title of a work by the writer Zakes Mda (2009) who offers in his novel, a nuanced and complex vision of the new urban Black middle class without any element of moral condemnation. Since May 2011 it can even be found as a heading in Wikipedia which describes it as both a 'racial term' and 'pejorative'.

Walter Benjamin (2006), when writing about the construction of urban social types in Europe, refers to moral portraits typically produced by a "panoramic literature" as a 'phantasmagoria'. He applied this metaphor, taken from a kind of magic lantern show, to Paris's shopping arcades, built at the birth of modern capitalism, which he saw as spectacular theatres of the new commodity culture. In contemporary South Africa, there is no shortage of shopping malls or of moral portraits depicting their denizens. The lifestyle categories that circulate as a result make up for their lack of scientific status by the sheer volume of their public iteration. The stereotype of the 'Black diamonds', built up around an imagined life-style, goes with a matching set of 'moral' characteristics that are reminiscent of the phantasmagoria.

Moral portraits of the Black Diamonds rely mainly on descriptions of consumer behaviour. The long history of economic inequality has yielded a model of cultural legitimacy in which 'good practice', with reference to money and consumption in particular, is implicitly taken to be White. An illusion that diverts and distracts us from reality ${ }^{4}$, the Black Diamond label masks what is really at stake in society and politics, in this case the persistence of racial stigma and of a behavioural standard based on the White minority. Morally loaded descriptions range between two poles: anxiously

\footnotetext{
${ }^{4}$ Benjamin's critique of capitalism as a dream, as famously developed in the Passagenwerk, known in English as The Arcades Project (1999), lies beyond the scope of this article.
} 
positive at one end, disapproving, even stigmatizing at the other. The first extreme celebrates the new middle class, while passing over the conditions of its emergence, especially the racial dimension contained in the label itself. The second depicts an alienated group forgetful of its social obligations after discovering the joys of money and consumption. To borrow the terminology of two sociologists close to Bourdieu, Passeron and Grignon (1989), media discourse is sometimes populist, sometimes "miserabilist", more often the latter.

So what are the Black Diamonds supposed to get up to? Their life-style apparently leaves little to be desired when compared with the 'conspicuous consumption' of the nouveaux riches Americans described by Thorstein Veblen (1899); for these consumers, prestige was the only consideration ${ }^{5}$. In short their consumption is conspicuous and is described as such, not only by the media, but also by the specialists I interviewed (marketing and advertising experts). Some articles express reservations about it all: ostentatious display of wealth by the new Black middle class is thought to be in bad taste for a country with so many poor people. Against the moralizers, blogger Sentletse Diakanyo ${ }^{6}$ has come to the defence of conspicuous consumption on his fellow-citizens' part by appealing to the central idea of Adam Smith's Wealth of Nations (1776), namely that the pursuit of individual self-interest is the motor of economic development. At the same time, he draws on a psychological argument produced by a study of Black and Hispanic consumer behaviour in the United States: conspicuous consumption is a response to historical deprivation by groups who wish to affirm their new social standing. Comments on this blog post were mixed; but their sheer number shows the level of interest among his readers, most of whom had little time for the moralizers. Even though my informants are lower middle class, the ubiquity of the term 'Black Diamonds' and the descriptions attached to it affect them too, since the distinction between lower and upper middle classes is usually collapsed in such discourses. I

\footnotetext{
${ }^{5}$ Conspicuous consumption has its own television programme in South Africa, Top Billing
} (SABC3), every Thursday evening, plus a magazine of the same name. This programme shows luxurious domestic interiors and celebrations (above all marriages) with protagonists from all the country's communities.

${ }^{6}$ http://www.thoughtleader.co.za/sentletsediakanyo/2010/12/03/in-defence-of-conspicuousconsumption 
should point out, however, that my informants often rejected application of the term 'middle class' to themselves, preferring to known as a 'professional' class. They are teachers, nurses, technicians, librarians, secretaries, police officers, independent consultants, etc. There has been such an African professional class long before 1994, of course. It is not an invention of 'democracy'.

\section{Conclusions}

I am less concerned here with the construction of an urban social type or with defining class according to income - which is in any case hard to find out - than with trying to understand how the middle class might be identified through common practices, in the home as much as in newly shared social spaces.

If Durban's middle classes don't define themselves through their eating and cooking habits, these practices have become quite similar across the boundaries between communities. The fast-food chains facilitate this process of self-identification at a number of levels; through the food styles on offer, they make South Africa at once an international and a national, even African place. Restaurants allow one to eat a neighbour's food, without knowing how to make it oneself - curry or fish, for example, and I would add without necessarily meeting their neighbours; which is a general paradox inherent in consuming commodities. The range of possibilities on offer through manufactured food and restaurants no doubt contributes to the development of a national taste, but also to a regional taste specific in this instance to Kwazulu Natal. I would not go so far, however, as to say that a specifically South African cuisine has yet emerged from all these culinary encounters, certainly not anything that we could call a creole food culture (Wilk, 2006a and 2006b) ${ }^{7}$. I have also been struck by how the

\footnotetext{
${ }^{7}$ I should mention here the cooking book "Indian Delights" (published in 1961 with many revisions and more than 150,000 copies sold, well beyond the Indian community). Its recipes claim to be both typically Indian and different from those of India and Pakistan. This book was written by Zuleikha May for the Women's Cultural Group. Some elements of African cooking, such as a 'curry-pap' are integrated into the recipes. See also Vahed and Waetjen (2010), Wardrop (2012).
} 
experts, magazines, TV shows, books and food fairs advance recipes that both take into account South African 'reality' and help to build a supra- regional universe consisting of English-speakers living in the southern hemisphere. This cuisine is built on recipes using a similar range of ingredients and promoted by chefs from Australia and South Africa in particular. Following Appadurai (1988), one might say they are building a new ethnoscape on the basis of shared food tastes. At the same time each group has its 'soul food', usually focused on a highly-charged symbolic food, meat, although the penchant of white settlers for outdoor barbecues is a common element for some.

Analysis of consumption patterns, taking into account historical context and generational difference, and especially of food consumption, because it is literally incorporated so deeply into social life, helps us to understand better the articulation and transformations of race and class identities which for so long were inseparable. These transformations contribute also to a new definition of regional and South African identity. Consumption is rightly considered to be a political question. It should not be left as the exclusive province of lifestyle professionals, such as marketers and journalists.

Appadurai, A., 1988. How to make a national cuisine: cookbooks in contemporary India. Comparative Studies in Society and History, 30 (1), 3-24.

Ballard, Richard, 2004. When in Rome: Claiming the right to define neighbourhood character in South Africa's suburbs. Transformation, $\mathrm{n}^{\circ}$ 57, p. 64-87.

Benjamin, W. 1999. The Arcades Project. Harvard University Press, Cambridge.

Benjamin, W. 2006. The Writer on Modern Life: Essays on Charles Baudelaire. Cambridge MA: Harvard University Press.

Braudel, F. 1961. Alimentation et catégories de l'histoire. Annales. Économies, Sociétés, Civilisations. 16e année, N. 4, 723-728.

Burgess, S. M., 2002. SA Tribes: Who we are, how we live and what we want from life in the New South Africa. Cape Town: David Philip. 
Chevalier, S. 1997. L'idéologie culinaire en Angleterre ou comment séparer le blanc du jaune in Pratiques alimentaires et identités culturelles. Ethnologie Française, $\mathrm{n}^{\circ} 1$, tome XXVII, 73- 79.

Chevalier, S. 2007. Faire ses courses en voisin: pratiques d'approvisionnement et sociabilité dans l'espace de trois quartiers de centre ville (Paris, Lyon et Besançon). www.revue- metropoles.com, $\mathrm{N}^{\circ} 1$.

Chevalier, S. 2010. Les Black Diamonds existent-ils? Médias, consommation et classe moyenne noire en Afrique du Sud. Sociologies Pratiques, n²0, 75-86.

Chevalier, S. and E. Escusa, 2011. Les pratiques alimentaires des classes moyennes sudafricaines, Rapport de recherche pour l'entreprise Bel, Septembre. 78 pages.

Chevalier, S. 2012. Comment partager les mêmes espaces? Les classes moyennes à Durban (Afrique du Sud). Espaces et Sociétés. 148-149 (1),129-144.

Counihan, C.M., 1998. Introduction: food and gender: identity and power. In Counihan, C.M. and S.L. Kaplan (ED), Food and gender: identity and power, pp. 1-11. Amsterdam, Harwood Academic.

Febvre, L. 1961. Essai de carte des graisses de cuisine en France. Annales. Économies, Sociétés, Civilisations. 16e année, N. 4, 1961, 747-756.

Goody, J. 1982. Cooking, Cuisine and Class : A Study in Comparative Sociology. Cambridge, CUP.

Heinze, A. 1990. Jews immigrants, mass consumption and the search for American identity. New-York, University of Columbia Press.

Houssay-Holzschuch M., Teppo A., 2009. A mall for all? Race and Public Space in post- apartheid Cape Town. Cultural Geographies, $\mathrm{n}^{\circ} 3$.

James, D. 2012. Money-go-round: personal economies of wealth, aspiration and indebtedness. Africa, 82 (1), 20-40.

Krige, D. 2011. Power, identity and agency at work in the popular economies of Soweto and Black Johannesburg. Unpublished PhD dissertation, Social Anthropology, University of Witwatersrand, Johannesburg.

Leong-Salobir, C. 2011. Food Culture in Colonial Asia: A Taste of Empire. Routledge, London.

Mauss, M. 1947. Manuel d'ethnographie. Paris, Payot. Mda, Z. 2009. Black Diamond. London : Penguin.

Miller, D. 1998. A Theory of Shopping. Cambridge, Polity Press.

Miller, D. 2001. Dialectics of Shopping. Chicago, University of Chicago Press. 
National Credit Regulator (2012) Consumer Credit Market Report, First Quarter March 2012. http://www.nca.org.za.

Passeron, J.-Cl. and Cl. Grignon. 1989. Le savant et le populaire. Misérabilisme et populisme en sociologie et en littérature. Paris, Seuil.

Strasser, S., C. McGovern and M. Judt. 1998. Getting and Spending. Cambridge, CUP. Vahed G and Waetjen. 2010. Gender, Modernity and Indian Delights: The Women's Cultural Group in Durban, 1954-2010. Cape Town, HSRC.

Vahed G. and Desai, A. 2013. Trading in the township: A checkered history. In Desai and Vahed. Chatsworth, the making of a South African Township. Durban, UKZN Press, pp. 349-360.

Veblen, T. 1992/1899. The Theory of the Leisure Class. New Brunswick: Transaction Publishers.

Wardrop, J. 2012. Speaking out loud: Muslim women, Indian Delights and culinary practices in eThekwini/Durban. Social Dynamics, 38, 2, 221-236.

Wilk, R. 2006a. Home Cooking in the Global Village: Caribbean Food from Buccaneers to Ecotourists. Berg Publishers.

Wilk, R. 2006b. Fast Food/ Slow Food: The Cultural Economy of the Global Food System. Altamira Press.

Wood, S. 2011. Forerunners, 52 (film, South Africa).

Zelizer, V. 1997. The Social Meaning of Money. Princeton: Princeton University. 